IJOLTL, Vol. 3, No. 1, January 2018

p ISSN: 2502 2326; e -ISSN: 2502 8278

Http://ijolt1.pusatbahasa.or.id; Email: ijolt1@gmail.com

Center of Language and Culture Studies, Surakarta, Indonesia

Maulina, Hanna Oktalifa, Suyitno \& Wardani, Eko Nugraheni. 2018. Genetic Structuralism

and Value of Character Education in the Monologue Matinya Toekang Kritik, the Death of Criticizers by Agus Noor, IJOLTL (2018), 3(1): 89 102.

DOI: 10.30957/ijoltl.v3i1.411.

\title{
GENETIC STRUCTURALISM AND VALUE OF CHARACTER EDUCATION \\ IN THE MONOLOGUE MATINYA TOEKANG KRITIK, THE DEATH OF CRITICIZERS BY AGUS NOOR
}

\author{
Oktalifa Hanna Maulina ${ }^{1}$, Suyitno ${ }^{2}$, Nugraheni Eko Wardani ${ }^{3}$ \\ ${ }^{1}$ Thesis Supervisee; ${ }^{2 \& 3}$ Thesis Supervisors \\ Graduate Program of Indonesian Language Education \\ Sebelas Maret University \\ Jl. Ir. Sutami 36 A Kentingan Surakarta, Central Java, Indonesia \\ E-mail: oktalifahanna14@gmail.com
}

\begin{abstract}
The aims of this research are to describe writer's point of view of Agus Noor on monologue Matinya Toekang Kritik, the Death of Criticisers, text structure, social structure, and tolerance attitude as the character building values in the work. This research is the descriptive qualitative research. Data were validated using theory triangulation and data triangulation. The data were analyzed using interactive analysis techniques and content analysis. The results are: (1) Drama writer group's point of view is social humanism, (2) Monolog text structure describes demonstrative life with Javanese values that found through structuralism analysis approach, (3) Monologue text structure is divided into harmony, honourability, the lifestyle of priyayi and wong cilik and also the relationship between priyayi and government, and (4) The most dominant character building is tolerance shown explicitly or implicitly by the players.
\end{abstract}

Keywords: Genetic Structuralism, character building value, monologue, Matinya Toekang Kritik

DOI: 10.30957/ijoltl.v3i1.411.

\section{INTRODUCTION}

Literary works can show a particular social and cultural circumstance of a particular society. This can be realized from the creative idea of the author based on the phenomena that occur in the community. The existence of a good relationship between the author with the environment (social relations) it will certainly produce a quality work.

Social relationships are woven by the author, will affect the results of his work so that it can be used as a social document with the characteristics of each genesis. This is, in line with what Ratna (2013:77) says, social relationships explain the genesis of works as one of the consequences of the interaction of various interactions that occur. The 
IJOLTL, Vol. 3, No. 1, January 2018

p ISSN: 2502 2326; e -ISSN: 2502 8278

Http://ijolt1.pusatbahasa.or.id; Email: ijolt1@gmail.com

Center of Language and Culture Studies, Surakarta, Indonesia

Maulina, Hanna Oktalifa, Suyitno \& Wardani, Eko Nugraheni. 2018. Genetic Structuralism

and Value of Character Education in the Monologue Matinya Toekang Kritik, the Death of Criticizers by Agus Noor, IJOLTL (2018), 3(1): 89 102.

DOI: 10.30957/ijoltl.v3i1.411.

genesis of literary works, which are generally apparent in the modes of worldview, must be traced within a volatile social structure. Literary works are not born naturally, literary works are also not born under special conditions; therefore, literary works cannot be regarded as unique phenomena. Literary works are social interaction responses through the personality of the artist, not the personality of the artist.

Albertazzi (2010) in the results of his research also states that literature is a product as well as part of the social reality of society. Most literary objects have a close relationship with social reality, so the sociology of literature is quite dominant. The point is dominant here that the sociology of literature balances the view of the reader, the mimetic, the literary work itself and of course the great influence of the worldview of the author.

One response artist/author to be able to convey his aspirate, his criticism, or show the existence of self and the cultural social environment is with drama, considering the drama is one genre of literary works. According to Dewojati (2012:16) like the drama's fiction tells stories like poetry, drama plays words with imagination. However, the drama has its own peculiarities when compared with other genres such as novels, short stories, and poetry. The publication of novels or other prose stories aims to be enjoyed by readers, the readers who enjoy the written works are individual readers. Another case with drama, a drama is created to be staged and enjoyed together.

Drama can be enjoyed from various sides, both when reading in the form of text (literature) or enjoyed in the form of performances. Thus, the drama can be said to be a multidimensional literary work. The drama text is said to be multidimensional, meaning either the value or function cannot be abandoned.

Indonesian dramas tend to highlight politics, morals, economics, households, education and so on. These problems when examined turn out to include human and social relations, considering one of human nature is a social creature.

One prolific writer is known as a short story writer, prose writer, TV scriptwriter, and also drama scriptwriter Agus Noor who has uniqueness and uniqueness in the style of writing. He is known as a writer who can combine parody stories with satirical languages. The famous monologue contains its writing style, namely the monologue Matinya Toekang Kritik.

The monologue of Matinya Toekang Kritik is a manuscript written by Agus Noor that aims to assert to the public that the critic is always alive in every age. In the monologue, the reader/viewer can then see how a critic is right and who is not. With the monologue was also inspired the birth of a television program titled "Republik Sentilan Sentilun" which aired in one of the private stations to date.

The conflicts contained in the text also have much to do with social inequalities and moral degradation in Indonesia. The initial setting of this drama story was shown in 1989 at which time Indonesia was in a crisis. Starting from this, the criticism began to sound active. There are also in some settings, figures associate the story with the stories of the ancient kingdom or previous civilization just as an interesting comparator. After 
IJOLTL, Vol. 3, No. 1, January 2018

p-ISSN: 2502 2326; e-ISSN: 2502 8278

Http://ijolt1.pusatbahasa.or.id; Email: ijolt1@gmail.com

Center of Language and Culture Studies, Surakarta, Indonesia

Maulina, Hanna Oktalifa, Suyitno \& Wardani, Eko Nugraheni. 2018. Genetic Structuralism

and Value of Character Education in the Monologue Matinya Toekang Kritik, the Death of Criticizers by Agus Noor, IJOLTL (2018), 3(1): 89 102.

DOI: 10.30957/ijoltl.v3i1.411.

repeated readings the manuscript always shows that there will always be a group of people who criticize the ruler of his country (government) at that time.

The text of the monologue Matinya Toekang Kritik contains many aspects of social protest and the designation of the existence of the author that he and his environment also cannot be separated from the part of people who like to criticize. Thus, the monologue contains many secrets if not studied to know the author's worldview and the various influences of his social-cultural life in producing the monologue.

The study of genetic structuralism is sufficiently appropriate to know the sociocultural background and answer what his worldview is when creating the monologue. In accordance with the disclosed Lucien Goldman (in Wardani, 2009:47) in his theory that, the approach of genetic structuralism trying to find a combination of text structure with social structure because the principle of this approach also takes into account social factors that affect the birth of literary works and review the structure of related texts with social conditions and social groups. In other words, this approach recognizes the homology between literary structures and certain social structures.

Another thing that attracts this monologue is the value of character education. One effort to be able to provide meaningful learning to the community (students/ students) that is with the character education that is owned in each subject. Hasanah (2013:187188) also emphasized the importance of character education value from its goal which is basically to encourage the birth of a good human being, who has an interesting personality, ethical, earthy, honest, intelligent, caring and tough. Growing and developing a good character will encourage learners to grow with the capacity and commitment to do the best things. And can do everything right and have a purpose in life.

The goal to be achieved is packaged in various values. One is the value of tolerance. Endang (2009:92) in the results of his research interpret tolerance as a diversity that develops, both religious diversity, culture, and including habits or customs. Given this diversity, then the value of tolerance is needed to reduce the tension or conflicts that can happen. The monologue for Toekang Kritik also highlights the issue of tolerance, so it is appropriate to be explored and utilized for learning the value of character education.

Based on the background explanation of the above issues, the purpose of writing this article as follows: 1) Exposing the author's worldview contained in the script monologue of Matinya Toekang Kritik by Agus Noor. Identify the structure of the monologue of Matinya Toekang Kritik by Agus Noor; 2) Describes the social structure Agus Noor author of monologue Matinya Toekang Kritik; and 3) exposing the educational value of the tolerant character contained in the monologue text of Matinya Toekang Kritik by Agus Noor.

\section{METHODS}


IJOLTL, Vol. 3, No. 1, January 2018

p ISSN: 2502 2326; e -ISSN: 2502 8278

Http://ijolt1.pusatbahasa.or.id; Email: ijolt1@gmail.com

Center of Language and Culture Studies, Surakarta, Indonesia

Maulina, Hanna Oktalifa, Suyitno \& Wardani, Eko Nugraheni. 2018. Genetic Structuralism

and Value of Character Education in the Monologue Matinya Toekang Kritik, the Death of Criticizers by Agus Noor, IJOLTL (2018), 3(1): 89 102.

DOI: 10.30957/ijoltl.v3i1.411.

To explain the purpose of this study used qualitative research methods with the approach of genetic structuralism. The source of the data used is the monologue drama script of Matinya Toekang Kritik by Agus Noor. Data were collected by way of referring, record, and interview. The data collection begins with a comprehensive reading of the monologue text of Matinya Toekang Kritik by Agus Noor, then when the data has been found can be done by way of recording. It is intended that the aspects that are found as data can be collected completely. The criteria used as a guide for the author's worldview, the structure of the text, the social structure, and the value of character education are conducted through several steps. Data validation techniques use triangulation theory and triangulation of data. Analysis of data used in the form of interactive data analysis according to Miles and Huberman (1994) through the data collection, data reduction, data presentation, and withdrawal of conclusions.

\section{FINDING AND DISCUSSION}

\subsection{Views of the Author World}

Agus Noor's worldview in his monologue of Matinya Toekang Kritik helps discover the author's imaginary world, making it easier to understand the structure of his work and its social structure. Agus Noor tends to have a socialist worldview that has a close relationship with his social group. Agus Noor and his social group are concerned with the policies of the authorities that are considered to be detrimental to the middle class or the small people. In addition, social attention is also evidenced in its criticality to the disharmony of Indonesian society.

The views on the above issue, raises the idea to reflect on them in various forms of literary works. No little influence and thoughts of Agus Noor social group can inspire in every creative process. Call it Emha Ainun Nadjib and Umar Kayam, they have a personal closeness with the two great writers. Of the two, Agus Noor studied and was formed to become a writer.

The personal closeness that was built with the two writers, made Agus Noor have the same attention to the issues that developed in the community. The form of disclosure in his works also has a strong influence from Emha Ainun Nadjib in his scriptwriting style. Like Umar Kayam, Agus Noor also presents works that have a Javanese cultural background, both in terms of background use, Javanese puppet story shoots, as well as ethical Javanese values.

The writer Putu Wijaya, also has a name having similar views with Agus Noor. In addition to the form of the disclosure of his story was filled with the tone of cynicism but witty. Agus Noor also has a tendency like Putu Wijaya in raising the story of human alienation.

The social group of Agus Noor can be categorized as a group of priyayi, in Javanese culture, and is an educated priyayi or scholar. This is seen from the authorship profile of social groups Agus Noor who has the skills of science and experience, so it can be concluded social group is social humanism. As disclosed by Sindhunata (in 
IJOLTL, Vol. 3, No. 1, January 2018

p ISSN: 2502 2326; e -ISSN: 2502 8278

Http://ijolt1.pusatbahasa.or.id; Email: ijolt1@gmail.com

Center of Language and Culture Studies, Surakarta, Indonesia

Maulina, Hanna Oktalifa, Suyitno \& Wardani, Eko Nugraheni. 2018. Genetic Structuralism

and Value of Character Education in the Monologue Matinya Toekang Kritik, the Death of Criticizers by Agus Noor, IJOLTL (2018), 3(1): 89 102.

DOI: 10.30957/ijoltl.v3i1.411.

Wardani, 2009:53) that social humanism contains the value of solidarity to bring and help others in obtaining human dignity.

The worldview of Agus Noor has in common with the views of its social group, social humanism. This is adapted to its characteristics which can be classified in the priyayi group of scholars. Thus, Agus Noor's worldview is portrayed in his monologue Matinya Toekang Kritik which leads to a view of the world of social humanism.

Suhikayatno, is the main character used by Agus Noor in representing his worldview of social humanism. It is said that the main character is a priyayi who has an upper middle social class and has a position that feels important to people who know him. Kepriyayian Raden Mas Suhikayatno is much shown in the use of dialogue and a picture of the daily atmosphere of a Javanese priyayi. Here is a part of the story that shows the social class of the main character in the monologue Matinya Toekang Kritik.

"Raden Mas Suhikayatno berjalan kearah meja yang di tempatkan sedemikian rupa menurut kebutuhan tata setting dan artistik. Meja itu bergaya kuno, dengan sepasang kursi yang juga tua. Mengingatkan pada perabot seorang priyayi Jawa. Ada cangkir dan gelas di atas meja itu. Juga majalah dan koran yang tak rapi. Raden Mas Suhikayatno yang kecapaian karena terus-terusan bercerita, segera duduk di kursi. Menikmati minuman. Tapi kaget tersedak..."

The quotation above shows the existence of the daily pattern of a priyayi who has rules in any case, even in the arrangement of home furnishings.

The figure is also described as a priyayi accustomed to the ordinary manners of the nobles, reflected while sitting in his rocking chair and enjoying his drink.

Another quote that shows that Raden Mas Suhikayatno, or summarized Denmas Suhikayatno has a close relationship with the rulers of the Javanese wayang world, such as King Hastina. In this monologue, it is depicted that the main character is a person who has surrealism. Here's the quote.

“Jangankan Presiden Indonesia...ditawarin jadi raja Hastina saja saya tidak mau kok. Emoh! Padahal Romo Semar sendiri lho yang nawarin. Katanya, saya ini lebih pantas jadi raja Hastina, ketimbang Yusdhistira, si Pandawa paling tua itu.

Saya ingat betul kok waktu itu...Itu jaman ketika belum ada kerajaankerajaan di Jawa. Tapi saya sudah ada. Sudah tua dan imut seperti ini.

Waktu itu terjadi krisis di Hastina, karena Pandawa kalah main dadu. Romo Semar langsung tergopoh gopoh menemui saya. (Bergaya wayang orang) "Kakang Raden Mas Suhikayatno, kamu harus menyelamatkan Hastina. Kamu harus jadi raja Hastina!” (Pause) Dengan halus saya menjawab, (kembali bergaya wayang orang) "Maaf, Dimas Semar..., maaf. Bukannya menolak, Dimas Semar. TapiMaaf, Dimas Semar..., maaf. Saya sama sekali 
IJOLTL, Vol. 3, No. 1, January 2018

p ISSN: 2502 2326; e -ISSN: 2502 8278

Http://ijolt1.pusatbahasa.or.id; Email: ijolt1@gmail.com

Center of Language and Culture Studies, Surakarta, Indonesia

Maulina, Hanna Oktalifa, Suyitno \& Wardani, Eko Nugraheni. 2018. Genetic Structuralism

and Value of Character Education in the Monologue Matinya Toekang Kritik, the Death of Criticizers by Agus Noor, IJOLTL (2018), 3(1): 89 102.

DOI: 10.30957/ijoltl.v3i1.411.

tidak punya cita-cita jadi raja di dunia wayang. Maaf lho, Dimas Semar..., maaf. Sekali lagi, maaf Dimas Semar...maaf...” (hlm. 4). “

The above quote shows that Agus Noor wants to show the life and personality of the character in another, surreal form. Given the picture of the closeness of the relationship with the Pandavas and Semar, increasingly shows that Denmas Suhikayatno is a priyayi people who have the character of nobility. Especially when the character tells that Semar asked him to lead the kingdom of Hastina. Although the story is clearly fictitious, it becomes the author's reliable way of showing the position of the nobility of a Suhikayatno.

As a critic, Suhikayatno has a tendency to defend the people, especially Wong Cilik. However, Suhikayatno's overly ambitious character makes everything appear to have an envy of the power he should be able to achieve.

Criticism of cynicism expressed by Suhikayatno shows how great his concern for the fate of the people who become victims. According to him, the leaders of this country have no influence whatsoever on things that can prosper the people. He also suggested that do not have the desire to become president.

Through Suhikayatno also, Agus Noor tried to imply the view of social humanism in the form of criticism of cynicism. Agus Noor always emphasizes the achievement of human dignity of Indonesia, either as rulers or small people, which in Javanese terms is called priyayi and wong cilik. In some of his works, including his monologue Matinya Toekang Kritik, he gives criticism to those who criticize, reflected in Suhikayatno, the principal protagonist in the monologue.

\subsection{Text Structure}

The structure of the text in genetic structuralism centers on the character as a hero. The hero character is the main character who experiences various events, and interacts with other characters and his world. In the monologue of $M T K$, who became the figure of Hero must be Raden Mas Suhikayatno, although in the end of his life is not heroic. The process that brought Suhikayatno became the main character, namely: Suhikayatno looking for confession; Suhikayatno has a close proximity to kings or rulers; he felt himself forgotten and no longer remembered by the times; his anxiety is so burdensome to the mind; then died; mail arrives; the admission of his arrival on the day of his death.

Suhikayatno's relationship with Bambang brings the expression of the worldview of social humanism. Through his worldview, Agus Noor criticizes critical craftsmen who are inconsistent with what he criticizes. Too many, the author has found the critics or the opponents who have a purpose hidden behind his criticism. Through this monologue of $M T K$ is expected to serve as a reminder and contemplation to those who like to criticize to remain critical in terms of prospering the people. For the average person too, it can be a lesson to be careful not to be easily provoked when there are things that concern the interests of many people. 
IJOLTL, Vol. 3, No. 1, January 2018

p ISSN: 2502 2326; e -ISSN: 2502 8278

Http://ijolt1.pusatbahasa.or.id; Email: ijolt1@gmail.com

Center of Language and Culture Studies, Surakarta, Indonesia

Maulina, Hanna Oktalifa, Suyitno \& Wardani, Eko Nugraheni. 2018. Genetic Structuralism

and Value of Character Education in the Monologue Matinya Toekang Kritik, the Death of Criticizers by Agus Noor, IJOLTL (2018), 3(1): 89 102.

DOI: 10.30957/ijoltl.v3i1.411.

The monologue text structureof $M T K$ according to the view of genetic structuralism in the form of a relationship between the character and with the world .. Those figures that then play a role to develop events with tragic paths. This is in accordance with what is expressed by Teeuw (2013:94-95), that in order to produce a whole plot, it must consider the following points, namely order means order and rules; amplitude is the development of a plausible event; unity all plot elements must exist; and the coherence of the things that must happen in the whole plot.

Based on the above exposure, the structure of literary works can be done with structuralism approach and genetic structuralism approach. The difference between the two has its own focus on determining the overall meaning, and the two are complementary. In structuralism, the emphasis on the study of the elements of the work builder itself includes themes, characterizations, plots, and backgrounds or more autonomous in studying a literary work. In contrast to the genetic structuralism that emphasizes the study of heroes who brought the author's worldview through his relationship with other figures and with his world.

\subsection{Social Structure}

The social structure becomes one of the stages of interrelated analysis in a research of literary works. A work will not fulfill the meaning of totality or real meaning if it is only analyzed on one particular element only. Ratna (2007:80) complements that the relevance of interrelationship principles to the analysis of literary works will lead researchers to pay attention to every element that is inseparable from other elements. Therefore, interrelationship analysis is what makes literature, a society, and various phenomena that exist finally have a real meaning.

Society as a social agent has a tendency to have a close relationship with literary works. It is based on the substance of literary works that can cover all aspects of human life, so many values or norms that can be used as a reflection of self. In addition, through the ability of literary works that many aspirations of represented communities.

The analysis of the social structure is the stage of Lucien Goldman's structuralism study. In the previous section, we have presented an analysis of the author's worldview and work structure. Furthermore, in this section will be presented in the analysis of social structure. The discussion of the social structure must be closely related to the background of the author, as the creator of a work.

The monologue of MTK takes the background of Javanese culture, showing how the pattern of leadership and social situation effects experienced by the Javanese. This contextual monologue text also attempts to connect Indonesian leaders from Java. Thus, the criticality given by Agus Noor not only deals with the social structure of Java, but also attempts to uncover public secrets about the criticality of society overpower.

Agus Noor implicated in this monologue the existence of Javanese politics that occurred in the world of Indonesian politics. Javanese politics is like a Javanese letter when dipangku, then it dies. The analogy is shown to critics or opponents, who at first 
IJOLTL, Vol. 3, No. 1, January 2018

p ISSN: 2502 2326; e -ISSN: 2502 8278

Http://ijolt1.pusatbahasa.or.id; Email: ijolt1@gmail.com

Center of Language and Culture Studies, Surakarta, Indonesia

Maulina, Hanna Oktalifa, Suyitno \& Wardani, Eko Nugraheni. 2018. Genetic Structuralism

and Value of Character Education in the Monologue Matinya Toekang Kritik, the Death of Criticizers by Agus Noor, IJOLTL (2018), 3(1): 89 102.

DOI: 10.30957/ijoltl.v3i1.411.

zeal criticized the various government policies or social problems that exist, then after gaining power, he was silent as if forgot what he had been criticized. Therefore, a thick text with his guyon parikno or innuendos is very important to examine its social structure. Related to this matter, the discussion of social structure in Agus Noor monologue of MTK will be divided into: (1) Javanese priyayi Social Structure, (2) Javanese priyayi Lifestyle, and (3) Javanese priyayi Relation with State. Here's the exposure.

\subsubsection{Social Structure of Java Priyayi}

The social structure of hero, Raden Mas Suhikayatno, is a Javanese priyayi. In his household life, he was always assisted by a loyal assistant, Bambang. Both are clearly in two different class structures. Therefore, it is worth analyzing related to the relationship of both seen from the social perspective of Java. In this case it includes two things: (a) Principle of harmony and (b) Principle of Respect.

\subsubsection{The principle of harmony}

The principle of harmony is expressed by avoiding conflict, conducted by Bambang in the monologue of MTK. He as a servant always trying to create a harmony that occurred in the home his ndoro. However, sometimes it does so because he does not want to make Suhikayatno angry or offended. Therefore, the form of avoidance of the conflict resulted in the behavior of ngrasani or gossip. Here's the proof of the quote.

"Bambang: (Tergeragap) Ehh...iya, Tuan... (kepada penonton) Tuh 'kan, apa saya bilang. Beliau itu orang hebat. Seperti wali. Kalau digunjingin langsung kerasa (hlm. 9).”

The quote above shows that between Suhikayatno and Bambang there is no openness. Both still sort of in a stage of mutual need, so they cannot express each other and provide useful criticism. Not only Bambang, Suhikayatno as the priyayi also did the same thing as his maid, the following quotes.

"Denmas: (Mengomel sambil mengambili majalah dan koran) Meja sampai berantakan begini...(Mencari-carise suatu di tumpukan Koran dan majalah itu, sambil terus ngomel dan memanggil) Mbang, apa ada surat buat saya?...Saya 'kan sudah bilang, semua mest irapi. Biar saya tidak bingung begini. Dibilangin dari dulu, eh tetap nggak didengerin. Apa sih susahnya ndengerin. Dibilangin baik-baik, eh malah ngata-ngatain, "Dasar Tukang Kritiksirik!" (hlm. 5)."

Suhikayatno turns out to show the same form, namely assessing Bambang by way of ngrasani. In the quote, he was visibly upset with Bambang because his work was not tidy, according to Suhikayatno's version. But he says if Bambang hears that, his assistant maid will be ngedumel if Denmas is the Critic of Sirik. 
IJOLTL, Vol. 3, No. 1, January 2018

p ISSN: 2502 2326; e -ISSN: 2502 8278

Http://ijolt1.pusatbahasa.or.id; Email: ijolt1@gmail.com

Center of Language and Culture Studies, Surakarta, Indonesia

Maulina, Hanna Oktalifa, Suyitno \& Wardani, Eko Nugraheni. 2018. Genetic Structuralism

and Value of Character Education in the Monologue Matinya Toekang Kritik, the Death of Criticizers by Agus Noor, IJOLTL (2018), 3(1): 89 102.

DOI: 10.30957/ijoltl.v3i1.411.

Based on the above explanation, it seems to have a correlation with the solution of the problem expressed by Magis-Suseno (in Wardani, 2009:240) that openness must still be carried out with the polite and self-knowing behavior as found in human moral ethics. For example, state governments should be a pioneer of a culture of good openness to the community.

\subsubsection{The principle of respect}

The principle of respect in Javanese perspective is meant to create mutual respect. Then there is a general statement that says we want to be respected, then we must also respect others. The priyayi, in this case, should be able to guide the wong cilik, so that between them grow the awareness to respect each other.

There is a negative effect of this principle of respect, the existence of a misappropriation of the meaning of respect itself. According to Wardani (2009:240), most high-ranking people just want to be served, respected, and obeyed. In fact, it should be their obligations that serve the community. It is also the main discussion in the monologue of MTK, namely the satire to reveal that society should be served. Such a paradox ultimately expressed by the author is made into the representation of roles played by Suhikayatno and Bambang who are actually inverted. It has been mentioned in the analysis of the structure of works that Bambang is actually a representation of the people's leaders who should serve, not served

The important meanings that exist in the monologue that pertains to the problem of misuse of power, seems in accordance with the opinion of Wardani (2009:241) that the stratification upon entitled to enjoy various facilities in the form of services of lower stratification. Then what happens is an arbitrary act, which is clearly contrary to morals and laws, but is considered relaxed by the perpetrators.

Based on the above explanation, it looks very sad because the social situation in Indonesia today also increasingly shows the sense of prestige. In some rulers, there are still many who utilize his power, so that has lost respect for others, especially the wong cilik. As a warning for the future, there should be measures that can erode such a bad character. For example, according to Koentjaraningrat (1984:271) that children should be taught respectfully to their parents and are obliged to do good. From that opinion, clearly shows the formation of the main character of a child is from the family, his parents. Therefore, one cultivation of respect for children is also important as stock in the future.

\subsubsection{Javanese Priyayi Life style}

The lifestyle of a priyayi is synonymous with the pattern of structured activity and the use of visible things. Participation in various forms of state such as ceremonies, incorporated in an organization / social institution, recreation patterns, from home forms, home furnishings, clothes, food and beverages, and all forms of educational and noble titles are some of the priyayi's lifestyles. 
IJOLTL, Vol. 3, No. 1, January 2018

p ISSN: 2502 2326; e -ISSN: 2502 8278

Http://ijolt1.pusatbahasa.or.id; Email: ijolt1@gmail.com

Center of Language and Culture Studies, Surakarta, Indonesia

Maulina, Hanna Oktalifa, Suyitno \& Wardani, Eko Nugraheni. 2018. Genetic Structuralism

and Value of Character Education in the Monologue Matinya Toekang Kritik, the Death of Criticizers by Agus Noor, IJOLTL (2018), 3(1): 89 102.

DOI: 10.30957/ijoltl.v3i1.411.

From the above explanation, Sartono Kartodirjo (in Wardani, 2009:242) argues that the orientation to status is highly prized by the priyayi. Education and work, as well as social mobility took place massively to enter the group. Given that, it will gradually lead to a lifestyle that interests the class and becomes a showpiece.

The above is never taught by Javanese philosophy. As an alus Javanese should be able to maintain its refinement in the public eye. Morally, the Javanese man is always taught to be humble by not showing off anything attached to him.

In the monologue of MTK, as a priyayi, Denmas Suhikayatno does not question all his possessions. That is, he never showed off his lifestyle, but he still often showcased his social status and social relationships with the rulers. This is what must be observed, to be careful of greed or lust that leads to selfishness in the self.

\subsubsection{Relationship of Javanese Priyayi with the State}

Priyayi as citizens also must implement and maintain peace in the life of the state. Given the government-led system of the president, with the assistance of the leaders in each body, the people, including the priyayi must be proactive in supporting the community welfare program, and critical in policies that sacrifice certain classes.

In accordance with the above statement, monologue of Matinya Toekang Kritik also menyentil things that are not true in the eyes of ordinary people about socialpolitical activities. The monologue was a post-reform response appropriate to sociocultural circumstances around 2004-2005 during the presidency of President Susilo Bambang Yudhoyono or SBY.

Around that year, the author sees more and more of the phenomenon in which the opponents or criticized people seem to be free, open to their voice in view of government activity at the time. Agus Noor as the author, as if repeated during the Soeharto regime that silenced the voice of the people, then after that there was a massive turmoil from the people who thirst to "voiced".

In the history of Indonesia, President Soeharto was the longest leader of this country, so he seemed to have absolute power. Saksono and Djoko (2011:164) confirmed that Soeharto obsessed as king. This is reflected from his words before the departure of the position that is, "lengser keprabon mandeg pandito". Because such a remark is only common to the ancient Javanese Kings who descended from the king's office and then became priests.

The constitutional tyrant built by Suharto resulted in the infertility of corruption, collusion, and nepotism at the time. Then there was the fear that it would happen again in about 2005. Therefore Agus Noor created this script, so as a reminder and comparison. The author's main response is indeed to the social setting of the Soeharto regime, as in the following quotation.

"Denmas: Sungguh..., saya tak menuntut apa-apa.... Tidakkah kalian ingat di tahun 1995, lebih lima belas tahun lampau, di zaman Soeharto...Ketika semua 
IJOLTL, Vol. 3, No. 1, January 2018

p ISSN: 2502 2326; e -ISSN: 2502 8278

Http://ijolt1.pusatbahasa.or.id; Email: ijolt1@gmail.com

Center of Language and Culture Studies, Surakarta, Indonesia

Maulina, Hanna Oktalifa, Suyitno \& Wardani, Eko Nugraheni. 2018. Genetic Structuralism

and Value of Character Education in the Monologue Matinya Toekang Kritik, the Death of Criticizers by Agus Noor, IJOLTL (2018), 3(1): 89 102.

DOI: 10.30957/ijoltl.v3i1.411.

bungkam...Tukang Kritik seperti sayalah yang mempertaruhkan nyawa. Ketika Koran dan majalah dibreidel... Ketika kalian masih takut bicara demokrasi...Tidakkah kalian ingat saya...(hlm. 14).”

The quote above shows the result of the relationship between the two backgrounds of the time. The political and state life shown by the rulers seems unhealthy, the freedom to speak out against the government, according to the author's analysis, it is nostalgic to let go of silence in opinion. However, it turns out that there are so many people who want to sit in the seat of power, enjoy all the luxury of free facilities. Thus, Suhikayatno was used as a symbol of critical people but demanded recognition for his critical efforts.

\section{4 The Value of Character Education Tolerance}

One of the values of character education is the value of tolerance. Tolerance can be interpreted as attitudes and activities that respect different religions, ethnic cultures, opinions, attitudes, and actions of others different from themselves.

The value of this tolerance education is generated by the principle of harmony that is intertwined. As expressed by Wardani (2009:239) attitude of harmonious through tolerance is a real action applied by humans, especially the Javanese. Maintaining harmony by way of tolerance will make humans give and accept differences. Therefore, the recognition of plurality remains unchallenged.

The monologue of $M T K$ also contributes to the development of character education. One of the most important in the monologue is the value of character education tolerance that can be taken from events and characterizations that exist. The values of tolerance emphasized on respect for differences of opinion, attitudes, and actions represented by the characters.

The value of tolerance education is represented by Suhikayatno's character when he accepts the attitude of the historical writers who do not include him as one of the founders of the nation. Actually, it is just guyon parikno, but there is still a good tolerance value. Then when there is an opinion that mentions the founders of the nation are the Fathers, Suhikayatno also just ask for him alone, without debating the matter is longer. Then in his last statement, Suhikayatno actually asked for tolerance, so that his actions, opinions, and services have been respected for so long.

The figure of Bambang also shows the form of learning the value of tolerance. Tolerance brought through Bambang's character is a form of tolerance he learned from the characteristics of Suhikayatno. By disclosing it, Bambang hopes that tolerance is acceptable to others. Here's the quote.

"Tuan saya orangnya eksentrik. Kerjanya nyalahin orang. Ada ajah yang diomelin. Inilah, itulah. Saya dikatain ginilah, gitulah. Tiap hari kerjan ya ngritiiiiikkkk melulu. Apa saja dikritiknya... Kalau Anda pakai kaos kuning, dan dia ngelihat, pasti langsung ngritik: "Ih kuning kayak tai..." Nanti kalau Anda 
IJOLTL, Vol. 3, No. 1, January 2018

p-ISSN: 2502 2326; e-ISSN: 2502 8278

Http://ijolt1.pusatbahasa.or.id; Email: ijolt1@gmail.com

Center of Language and Culture Studies, Surakarta, Indonesia

Maulina, Hanna Oktalifa, Suyitno \& Wardani, Eko Nugraheni. 2018. Genetic Structuralism

and Value of Character Education in the Monologue Matinya Toekang Kritik, the Death of Criticizers by Agus Noor, IJOLTL (2018), 3(1): 89 102.

DOI: 10.30957/ijoltl.v3i1.411.

ganti pakai kaos merah, tetep saja dikritik: "Ih, apa hebatnya kaos merah!”...(Begitu seterusnya) (hlm. 8). “

In the above quotation, the author deliberately inserts information on the value of tolerance. From the bad example, should be taken wisdom if it would be better appreciate the actions or opinions of others. That's because we do not know what the motive and why someone is doing the opposite of us.

\section{CONCLUSION}

The study of genetic structuralism in the monologue Matinya Toekang Kritik gives several conclusions, namely: First, Agus Noor in this monologue voiced the worldview of the social group of intellectuals, that is social humanism. Second, the text structure of MTK monologue is analyzed using structuralism approach which emphasizes on the study of the theme, message, plot, characterization, and background. This is in contrast to the structure of the text studied by the approach of genetic structuralism, which links the hero figure with other figures and with his world to seek authentic value.

Third, the social structure of MTK consists of: (1) The principle of harmony in the monologou of MTK described by Bambang who keep trying to maintain harmony in relation to Raden Mas Suhikayatno. As a little boy who feels the need of work, Bambang is always patient in the face of all kinds of orders of his master. The principle of harmony brought by Bambang seems to give meaning to the readers/viewers that, it should be the priyayi who can guide and nurture the wong cilik, which is more socially under the strata. (2) The principle of respect, the principle is shown by Bambang through the way of calling his boss with the nickname Tuan (Master). Bambang also said that he remained respectful with Suhikayatno even though his work was always criticized. Bambang's respectful attitude also arises because he always tried to live in harmony in the home of his ndoro. (3) The lifestyles of priyayi and wongs have a very distant contradiction. Priyayi is very concerned about all things are done because the social class inherent in him tend to have a structured lifestyle. (4) Priyayi relationship with the state, the term culture of sepi ing pamrih, rame ing pandum means to refrain from all the good that has been done. In political language, it can mean the right attitude for priyayi officials to refrain from satisfying personal motives and working hard for the sake of the state. Fourth, the value of tolerance character education is reflected in Suhikayatno and Bambang figures in various implied meals delivered by both.

\section{REFERENCES}

Albertazzi, Silvia. (2010). A Comparative Essay ON The Sociology of Litterature: Alice Munro's 'Unconsummated Relationship'. Journal of The Short Story in English, 55, 8-9. 
IJOLTL, Vol. 3, No. 1, January 2018

p ISSN: 2502 2326; e-ISSN: 2502 -8278

Http://ijolt1.pusatbahasa.or.id; Email: ijolt1@gmail.com

Center of Language and Culture Studies, Surakarta, Indonesia

Maulina, Hanna Oktalifa, Suyitno \& Wardani, Eko Nugraheni. 2018. Genetic Structuralism and Value of Character Education in the Monologue Matinya Toekang Kritik, the Death of Criticizers by Agus Noor, IJOLTL (2018), 3(1): 89 102.

DOI: 10.30957/ijoltl.v3i1.411.

Dewojati, Cahyaningrum. (2012). Drama (Sejarah, Teori, dan Penerapannya). Yogyakarta: Javakarsa Media.

Hidayatulloh, M. Furqon. (2010). Pendidikan Karakter:Membangun Peradaban Bangsa. Surakarta: Yuma Pustaka.

Ratna, Nyoman Kutha. (2007). Metodologi Penelitian: Kajian Budaya dan Ilmu Sosial Humaniora Pada Umumnya. Yogyakarta: PustakaPelajar.

Saksono, Ignas G. dan DjokoDwiyanto.(2011). Terbelahnya Kepribadian Orang Jawa (Antara Nilai-nilai Luhur dan Praktik Kehidupan). Yogyakarta: Keluarga Besar Mahernis.

Suseno, Franz Magnis. (2001). Etika Jawa (Sebuah Analisa Falsafi tentang Kebijaksanaan hidup Jawa. Jakarta: PT Gramedia PustakaUtama.

Waluyo, Herman J. (2001). Drama (Teoridan Pengajarannya). Yogyakarta: Hanindita Graha Widia.

Wardani, Nugraheni Eko. (2009). Makna Totalitas: Karya Sastra. Surakarta: UNS Press. 
IJOLTL, Vol. 3, No. 1, January 2018

p ISSN: 2502 2326; e -ISSN: 2502 8278

Http://ijolt1.pusatbahasa.or.id; Email: ijolt1@gmail.com

Center of Language and Culture Studies, Surakarta, Indonesia

Maulina, Hanna Oktalifa, Suyitno \& Wardani, Eko Nugraheni. 2018. Genetic Structuralism and Value of Character Education in the Monologue Matinya Toekang Kritik, the Death of Criticizers by Agus Noor, IJOLTL (2018), 3(1): 89 102.

DOI: 10.30957/ijoltl.v3i1.411. 